\title{
DAMPAK ERUPSI GUNUNG SINABUNG TERHADAP PRODUKSI DAN HARGA CABAI MERAH (Capsicum annum L.) (Desa: Beganding, Kecamatan Simpang Empat, Kab. Karo)
}

\author{
Oleh: \\ Nelly M. R. Sinaga ${ }^{1)}$, Effendi Lubis ${ }^{2)}$, dan Yan Khoriana Sinaga ${ }^{3)}$ \\ Universitas Darma Agung, Medan \\ E-Mail: \\ sinaganelly@gmail.com ${ }^{1)}$, efendilubis52@gmail.com ${ }^{2)}$, \\ orysinaga218@ gmail.com $^{3)}$
}

\begin{abstract}
This research aims at (1) finding the effects before and after the eruption of Sinabung mountain on production of red chili (Capsicum annumL.) in research area, (2) finding the effects before and after the eruption of Sinabung mountain on price of red chili (Capsicum annumL.), (3) finding the income of red chilli ((Capsicum annumL.) after the eruption of Sinabung mountain in research area. This research was conducted in Beganding village, Simpang Empat Sub-district, Karo regency, province of Sumatera Utara. Research sample was done by using Simple Random Sampling as many as 35 respondents from the total population 167 families. Method of data analysis was by paire sample t-test to find the difference between production and price of red chili(Capsicum annum L.)both before and after the eruption of Sinabung mountain and analysis of red chili farmers' income. Research findings show that there is a significant effect of red chili production in research area both before and after the eruption of Sinabung mountain. The production of red chili before the eruption of Sinabung mountain is as many as $1.932 \mathrm{~kg} / \mathrm{farmer}$ $>1.342 \mathrm{~kg} /$ farmer (after the eruption of Sinabung mountain) in which the difference is 2.237 $\mathrm{kg} /$ farmer. The income of chili farming before and after the eruption of Sinabung mountain was categorized "low" and the comparison indicator is UMK Karo Regency in 2017. It is Rp 2.051.267/month, meanwhile UMK Karo regency is Rp 2.619.234,41.
\end{abstract}

Keywords: Eruption of Sinabung Mountain, Production, Price of Red Chili both before and after eruption of Sinabung mountain, income of red chilifarmers

\section{PENDAhuluan}

Seiring dengan berkembangnya industri pangan nasional, cabai merah merupakan salah satu bahan baku yang dibutuhkan secara berkeseimbangan. Karena merupakan bahan pangan yang dikonsumsi setiap saat, maka cabai merah akan terus dibutuhkan dengan jumlah yang semakin meningkat seiring dengan pertumbuhan jumlah penduduk dan perekonomian nasional. Pola permintaan cabai relatif tetap sepanjang waktu, sedangkan produksi berkaitan dengan musim tanam. Dalam kesempatan seperti ini beruntung bagi petani yang dapat memproduksi cabai merah 
sepanjang tahun. Fenomena ini perlu diamati oleh petani yang ingin berbisnis cabai merah (Prajnanta, 1999).

Kecamtan Simpang Empat adalah sentra produksi cabai merah terbesar di Kabupaten Karo, pada tahun 2015 produksi cabai merah sebesar 9.369 ton dan pada tahun 2016 produksi cabai merah mengalami penurunan menjadi 5.768 ton. Menurunnya produksi cabai merah tiap tahunnya di Kecamatan Simpang Empat disebabkan oleh faktor alam seperti meletusnya Gunung Sinabung. Gunung Sinabung merupakan salah satu gunung didataran Tinggi Karo, Kabupaten Karo, Sumatera Utara, Indonesia. Koordinat puncak Gunung Sinabung adalah 3०10'12'LU dan 98'23'31'BT dengan puncak tertinggi 2.460 meter dpl yang mencapai puncak tertinggi di Sumatra Utara. Gunung ini belum pernah meletus sejak tahun 1600, tetapi mendadak aktif kembali dengan meletus pada tahun pada tahun 2010 (Martini, ddk. 2011).

Hasil letusan Gunung Sinabung berupa lava menyebar kebeberapa daerah disekitar Gunung Sinabung. Lava gunung ini mengalir ke lahan-lahan pertanian yang merupakan mata pencarian masyarakat. Hal ini mengakibatkan tanaman mengalami kelayuan dan mati dengan pembagian luas yang berbeda-beda, yakni tanamam pangan (jagung, padi, ubi jalar, kacang tanah) dan tanaman sayuran (cabai, tomat, kubis, kentang, petsai/sawi, dan lain-lain), serta tanaman perkebunan (kopi, kakao, dan lainlain) (Dinas pertanian 2014).

Tabel Produksi Tanaman Cabai Merah (Ton) di Kabupaten Karo menurut Kecamatan pada Tahun 2015-2016

\begin{tabular}{|l|l|r|r|}
\hline \multirow{2}{*}{ No. } & \multirow{2}{*}{ Kecamatan } & \multicolumn{2}{|c|}{ Produksi (Ton) } \\
\cline { 3 - 4 } & 2015 & \multicolumn{1}{|c|}{ 2016 } \\
\hline 1 & Mardinding & 47 & 1.231 \\
\hline 2 & Laubaleng & 2.815 & 28 \\
\hline 3 & Tigabinaga & 1.422 & 283 \\
\hline
\end{tabular}

\begin{tabular}{|c|c|c|c|}
\hline 4 & Juhar & 838 & 585 \\
\hline 5 & Munte & 3.170 & 744 \\
\hline 6 & Kutabuluh & 3.995 & 1.549 \\
\hline 7 & Payung & 3.219 & 5.708 \\
\hline 8 & Tiganderket & 985 & 1.409 \\
\hline 9 & $\begin{array}{l}\text { Simpang } \\
\text { Empat }\end{array}$ & 9.369 & 5.768 \\
\hline 10 & $\begin{array}{l}\text { Naman } \\
\text { Teran }\end{array}$ & 8.666 & 4.074 \\
\hline 11 & Merdeka & 966 & 980 \\
\hline 12 & Kabanjahe & 1.376 & 749 \\
\hline 13 & Brastagi & 1.482 & 1.950 \\
\hline 14 & Tigapanah & 3.533 & 3.955 \\
\hline 15 & $\begin{array}{l}\text { Dolat } \\
\text { Rakyat }\end{array}$ & 881 & 2.976 \\
\hline 16 & Merek & 3.537 & 974 \\
\hline 17 & Barus Jahe & 3.834 & 5.051 \\
\hline \multicolumn{2}{|r|}{ Jumlah } & 49.132 & 38.013 \\
\hline
\end{tabular}

Sumber: Dinas Pertanian dan Perkebunan Kabupaten Karo, Tahun 2017

Selain itu bencana alam mengakibatkan kesejahteraan masyarakat sangat memprihatinkan, terjadi inflasi komoditas pangan pada masyarakat akan menurunkan hak daya beli masyarakat (Dzikron, 2006). Disisi lain meletusnya Gunung Sinabung juga membawa keberuntungan seperti sumber mineral, bahan galian, sumber daya air, objek wisata dan untuk beberapa tahun ke depan, lahan pertanian disekitar gunung menjadi subur (Noor, 2006).

Meletusnya Gunung Sinabung sangat berpengaruh terhadap kehidupan para petani di Tanah Karo. Sebagian besar lahan pertanian di Tanah Karo rusak akibat dari erupsi Gunung Sinabung. Abu vulkanik yang terus menerus hingga saat ini merusak tanaman pangan dan holtikultura petani terutama tanaman cabai yang mengalami kerusakan hingga $367 \mathrm{Ha}$. Terjadinya erupsi Gunung Sinabung mengakibatkan sebagian lahan pertanian rusak sehingga kegiatan produksi pertanian menjadi terganggu. 
Letusan Gunung Sinabung merusak tanaman pertanian dan perkebunan. Dari seluas 3.863 ha tanaman enam kawasan, seluas 3.589 ha telah rusak akibat letusan. Hal ini kemudian berdampak pada kelangkaan bahan makanan, pasokan sayur dan buah menurun hingga 40\% karena banyak petani tidak berani memanen, karena takut bahaya letusan Gunung Sinabung. Produksi dan Rata-Rata Harga Cabai Merahdapat dilihat Tabel 1.2 di Tanah Karo yang mengalami penurunan dari tahun 2015 sampai dengan 2016 akibat Erupsi Gunung Sinabung.

Tabel Produksi dan Rata-Rata Harga Cabai Merah (Ton) Tahun 2015-2016 di Kabupaten Karo Sebelum dan Sesudah Gunung Sinabung.

\begin{tabular}{|c|c|c|c|}
\hline No & \multicolumn{2}{|c|}{ Uraian } & Cabai \\
\hline \multirow[t]{2}{*}{1.} & \multirow[t]{2}{*}{$\begin{array}{l}\text { Produksi } \\
\text { (Ton) }\end{array}$} & $\begin{array}{ll}\text { a. Sebelum } \\
\text { Erupsi } \\
\text { Gunung } \\
\text { Sinabung } \\
\end{array}$ & 49.132 \\
\hline & & $\begin{array}{ll}\text { b. Sesudah } \\
\text { Erupsi } \\
\text { Gunung } \\
\text { Sinabung }\end{array}$ & 38.013 \\
\hline \multirow[t]{2}{*}{2.} & \multirow[t]{2}{*}{$\begin{array}{l}\text { Harga } \\
(\mathrm{Rp})\end{array}$} & $\begin{array}{ll}\text { a. Sebelum } \\
\text { Erupsi } \\
\text { Gunung } \\
\text { Sinabung }\end{array}$ & $15 . .000$ \\
\hline & & $\begin{array}{l}\text { b. Sesudah } \\
\text { Erupsi } \\
\text { Gunung } \\
\text { Sinabung }\end{array}$ & 30.000 \\
\hline
\end{tabular}

Sumber : Dinas Pertanian Kabupaten Karo, Tahun 2017

Abu vulkanik selain menutupi jalan, rumah-rumah penduduk juga menutupi tanaman. Abu vulkanik berdampak pada 6 (enam) kecamatan disekitar Gunung Sinabung yaitu Kecamatan Namanteran, Kecamatan Simpang Empat, Kecamatan Merdeka, Kecamatan Dolat Rakyat, Kecamtan Barus Jahe, dan Kecamatan Berastagi. Gunung Sinabung yang meletus pada tahun 2010 dan terus berlanjut hingga 2018 berdampak terhadap kehidupan manusia. Dampaknya bergantung terhadap besarnya kekuatan letusan gunung api tersebut namun secara umum dampak yang mungkin terjadi terhadap sosial, ekonomi, dan kesehatan masyarakat khususnya sekitar lokasi gunung berapi tersebut. Letusan gunung juga menyebabkan perubahan kegiatan ekonomi daerah tersebut, hargaharga sayuran dan produksi pertanian, sedangkan masyarakat disekitar gunung sendiri tidak memperoleh pendapatan selama bencana (Tindaon, 2003).

Terjadinya erupsi Gunung Sinabung berdampak pada penurunan produksi tanaman cabai merah. Akibat dari penurunan produksi cabai merah tersebut, tentu sangat mempengaruhi pendapatan dari petani di Tanah Karo. Erupsi Gunung Sinabung yang masih terus berlangsung hingga saat ini dan tidak dapat dipastikan kapan akan berakhir akan menghawatirkan kehidupan petani yang berada disekitar Gunung Sinabung. Oleh karena itu, peneliti tertarik untuk melakukan penelitian yang berjudul "Dampak Erupsi Gunung Sinabung Terhadap Produksi dan Harga Cabai Merah yang bertempat di Desa Beganding, Kecamatan Simpang Empat Kabupaten Karo".

Adapun tujuan penelitian adalah:

1. Untuk mengetahui dampak sebelum dan sesudah erupsi Gunung Sinabungterhadap produksi cabai merah(Capsicum annum L.) di daerah penelitian.

2. Untuk mengetahui dampak sebelum dan sesudah erupsi Gunung Sinabung terhadap harga cabai merah(Capsicum annum L.) di daerah penelitian.

3. Untuk mengetahui tingkat pendapatan petani cabai merah (Capsicum annum L.) sesudah erupsi Gunung Sinabung di daerah penelitian. 


\section{METODE PELAKSANAAN}

\section{Lokasi dan Waktu Penelitian}

Penelitian ini dilaksanakan di Desa Beganding, Kecamatan Simpang Empat, Kabupaten Karo, Provinsi Sumatera Utara. Pemilihan lokasi penelitian dilakukan secara sengaja (purposive)dengan pertimbangan bahwa Kecamatan Simpang Empat merupakan daerah penghasil cabai merah terbesar di Kabupaten Karo.

\section{Metode Penelitian Sampel}

Responden dalam penelitian ini adalah petani yang mengusahakan tanaman cabai merah di Desa Beganding, Kecamatan Simpang Empat, Kabupaten Karo, Provinsi Sumatera Utara. Dengan jumlah populasi 167 kepala keluarga (kk), kemudian diambil sampel sebanyak 35. Metode penetapan besar sampel dilakukan dengan menggunakan metode Simple Random Sampling (acak sederhana) dengan rumus:

$$
n=\frac{\mathrm{N}}{1+\mathrm{N}(\mathrm{e})^{2}}
$$

Keterangan :

$n=$ Jumlah sampel

$\mathrm{N}=$ Jumlah populasi

$\mathrm{e}=$ taraf signifikan yang dikehendaki $(15 \%)$.

$$
\begin{gathered}
n=\frac{167}{1+167(0.0225)} \\
=\frac{167}{4,76}=35
\end{gathered}
$$

Pada penelitianini digunakan toleransi kesalahan sebesar $15 \%$ dari jumlah populasi 167 kepala keluarga (kk). Hasil perhitungan menunjukkan bahwa jumlah sampel yang diambil dari keseluruhan populasi yaitu sebanyak 35 sampel.

\section{Metode Pengumpulan Data}

Data yang dikumpulkan dalam penelitian ini adalah data primer dan data sekunder. Data primer diperoleh dari wawancara dan hasil pengumpulan data secara langsung kepada tiap petani di Desa Beganding, Kecamatan Simpang Empat, Kabupaten Karo yang dijadikan sampel dengan menggunakan instrumen berupa kuisioner.

Sedangkan data sekunder diperoleh dari instansi-instansi yang terkait seperti Badan Pusat Statistika Karo, Badan Pusat Statistika Sumatera Utara, dan Gabungan Kelompok Tani (GAPOKTAN) di Desa Beganding.

\section{Metode Analisis Data}

Penelitian ini adalah menggunakan analisis uji-t berpasangan (paired sample $t$ test). Uji-t berpasangan yaitu salah satu metode pengujian hipotesis dimana data yang digunakan tidak bebas (berpasangan). Ciri-ciri yang sering ditemui pada kasus yang berpasangan adalah satu individu (objek penelitian) dikenai dua perlakuan yang berbeda. Walaupun menggunakan individu yang sama, penelitian tetap memperoleh dua macam data sampel, yaitu data dari perlakuan pertama dan data dari perlakuan ke dua.

Untuk melihat perbedaan Produksi dan Harga tanaman cabai sebelum dan sesudah erupsi Gunung Sinabung di Kabupaten Karo dapat menggunakan uji statistik t-hitung berpasangan dengan formulasinya sebagai berikut:

$$
\mathrm{t}-\text { hitung }=\frac{\mathrm{d}-\mathrm{d}_{0}}{\mathrm{Sd} / \sqrt{\mathrm{db}}} ; \mathrm{db}=\mathrm{n}-1
$$

Dimana: 
$\mathrm{d}$ = rata-rata produksi dan harga cabai merah sesudah erupsi Gunung Sinabung.

do = rata-rata produksi dan harga cabai merah sebelum erupsi Gunung Sinabung.

$\mathrm{Sd}=$ standar devisi

$\mathrm{n}=$ jumlah data/sampel

$\mathrm{db}=$ derajat bebas

(Walpole, 1997).

Kriteria pengambilan keputusan:

1. Hipotesis - 1 menggunakan perbandingan antara t-hitung dengan t-tabel

Jika $-t_{\text {tabel }} \leq t_{\text {hitung }} \leq t_{\text {tabel }}$; tolak $H_{1}$ : terima $H_{0}$

Jika $-t_{\text {tabel }} \leq-t_{\text {hitung }}$ atau $t_{\text {hitung }} \geq$ $t_{\text {tabel }}$; tolak $H_{0}$ : terima $H_{1}$

2. Hipotesis -2 mengunakan nilai signifikan

Jika nilai signifikan $>0,05$; maka $H_{0}$ diterima $H_{1}$ ditolak

Jika nilai signifikan $<0,05$; maka $H_{0}$ ditolak $H_{1}$ diterima

Hipotesis yang diajukan adalah:

$H_{0}$ : Tidak terdapat perbedaan yang nyata produksi cabai merah dan harga cabai merah di Kabupaten Karo sebelum dan sesudah Erupsi Gunung Sinabung.

$H_{1}$ : Terdapat perbedaan yang nyata produksi cabai merah dan harga cabai merah di Kabupaten Karo sebelum dan sesudah erupsi Gunung Sinabung.

Pendapatan usahatani cabai merah selisih antara penerimaan yang diperoleh dari usahatani cabai merah dengan semua biaya untuk mengusahakan usahatani cabai merah. Rumus untuk menghitung besarnya pendapatan usahatani adalah:

$\mathrm{Pd}=\mathrm{TR}-\mathrm{TC}$
Keterangan:

$$
\begin{aligned}
& \mathrm{Pd}=\text { Pendapatan Usahatani }(\mathrm{Rp}) \\
& \mathrm{TR}=\text { Penerimaan Usahatani }(\mathrm{Rp}) \\
& \mathrm{TC}=\text { Biaya Usahatani }(\mathrm{Rp})
\end{aligned}
$$

(Soekartawi, 2002).

Selanjutnya tingkat pendapatan per petani yang sudah dikonversikan perbulan dibandingkan dengan Upah Minimum Kabupaten (UMK) Kabupaten Karo pada tahun 2018 sebesar Rp 2.619.234.41. Jika pendapatan lebih tinggi dari UMK maka tingkat pendapatan dikategorikan tinggi, sedangkan lebih kecil dari UMK sebesar Rp 2.619.234.41 maka tingkat pendapatan dikategorikan rendah.

\section{HASIL DAN PEMBAHASAN}

\section{Analisis Ekonomi Usahatani Cabai Merah}

\section{Sarana Produksi}

Usahatani cabai merah yang dikelola petani di Desa Beganding menggunakan berbagai sarana produksi, yaitu bibit, pupuk, dan pestisida. Jenis pupuk yang digunakan petani adalah Urea, ZA, SP-36, dan $\mathrm{KCl}$, sedangkan pestisida yang digunakan adalah Spontan dan Bestok. Jumlah penggunaan masing-masing sarana produksi pada usahatani cabai merah dengan rata-rata tertera pada Tabel 3.1.

Tabel Penggunaan Sarana Produksi Pada Usahatani Cabai Merah di Desa Beganding Per Petani Per Musim,Tahun 2018

\begin{tabular}{|l|l|r|r|}
\hline $\begin{array}{l}\mathbf{N} \\
\mathbf{0}\end{array}$ & \multicolumn{1}{|c|}{ Jenis } & \multicolumn{1}{|c|}{ Jumlah } & \multicolumn{1}{|c|}{ Rataan } \\
\hline $\mathbf{1 .}$ & Bibit (kg) & 186,00 & 5,31 \\
\hline $\mathbf{2}$ & Pupuk: & & \\
\cline { 2 - 4 } & $\begin{array}{c}\text { a) Kompos } \\
(\mathrm{kg})\end{array}$ & $35.157,00$ & $1.005,51$ \\
\hline
\end{tabular}




\begin{tabular}{|c|c|c|c|}
\hline \multicolumn{2}{|c|}{\begin{tabular}{l|l} 
& b) Urea $(\mathrm{kg})$
\end{tabular}} & $3.439,00$ & 98,26 \\
\hline & c) $\mathrm{SP}-36(\mathrm{~kg})$ & $2.537,00$ & 72,49 \\
\hline & d) $\mathrm{KCl}(\mathrm{kg})$ & $1.012,00$ & 28,91 \\
\hline & e) ZA (kg) & 878,00 & 25,09 \\
\hline \multirow[t]{3}{*}{3} & Pestisida: & & \\
\hline & 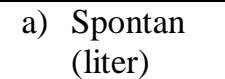 & 236,10 & 6,75 \\
\hline & $\begin{array}{l}\text { b) Bestok } \\
\text { (liter) }\end{array}$ & 230,30 & 6,58 \\
\hline \multicolumn{2}{|r|}{ Total } & $43.675,40$ & $1.248,9$ \\
\hline
\end{tabular}

Sumber: Data Diolah, Tahun 2018

Dari Tabel 3.1 terlihat jumlah total pemakaian sarana produksi yaitu 186,005 $\mathrm{kg}$ dengan rata-rata per petani sebesar 31 $\mathrm{kg}$ bibit, sedangkan jumlah penggunaan pupuk per petani yaitu Kompos sebesar $35.157,00 \mathrm{~kg}$ dengan rata-rata $1.005,51 \mathrm{~kg}$, Urea sebesar $3.439,00 \mathrm{~kg}$ dengan rata-rata 98,26kg, SP-36 sebesar 2.537,00 kg dengan rata-rata $72,49 \quad \mathrm{~kg}, \quad \mathrm{KCl}$ sebesar $1.012,00$ dengan rata-rata $28,91 \mathrm{~kg}$, dan ZA sebesar 878,00 dengan rata-rata $25,09 \mathrm{~kg}$. Selanjutnya jumlah penggunaan pestisida per petani yaitu236,10 liter dengan rata-rata 6,75liter Spontan dan Bestok sebesar 230,30 liter dengan rata-rata 6,58 liter. Semua sarana produksi tersebut diperoleh dari luar keluarga dengan cara membeli sesuai dengan harga yang berlaku di pasar. Dari harga pembelian dikali dengan jumlah penggunaan masing-masing sarana produksi diperoleh nilai sarana produksi seperti tertera pada Tabel 3.2.

Tabel Nilai Penggunaan Sarana Produksi Pada Usahatani Cabai Merah di Desa Beganding Per Petani Per Musim Tanam, Tahun 2018

\begin{tabular}{|l|l|r|c|}
\hline $\begin{array}{l}\text { N } \\
\mathbf{0}\end{array}$ & Jenis & Jumlah (Rp) & $\begin{array}{c}\text { Rataan } \\
(\mathrm{Rp})\end{array}$ \\
\hline 1. & Bibit & 11.160 .000 & 318.857 \\
\hline $\mathbf{2}$ & Pupuk: & & \\
\hline
\end{tabular}

\begin{tabular}{|l|l|r|r|}
\hline & a) Kompos & 52.789 .500 & 1.508 .271 \\
\hline & b) Urea & 6.878 .000 & 196.514 \\
\hline & c) SP-36 & 17.759 .000 & 507.400 \\
\hline & d) KCl & 5.060 .000 & 144.571 \\
\hline & e) ZA & 1.756 .000 & 50.171 \\
\hline $\mathbf{3}$ & Plh pupuk & 95.402 .500 & 2.725 .786 \\
\hline & a) Spontan & 10.624 .500 & 303.557 \\
\hline & b) Bestok & 10.363 .500 & 296.100 \\
\hline & Jlh pestisida & 20.988 .000 & 599.657 \\
\hline Total saprodi & 127.550 .500 & 3.644 .300 \\
\hline
\end{tabular}

Sumber: Data Diolah Tahun 2018

Dari Tabel 3.2 terlihat bahwa secara secara rata-rata nilai sarana produksi paling tinggi adalah pembelian Kompos, dengan nilai $\mathrm{Rp}$ 1.508.271 per petani. Secara keseluruhan total biaya produksi yang digunakan petani adalah $\operatorname{Rp} 3.644 .300$.

\section{Tenaga Kerja}

Tabel Rata-rata Penggunaan Tenaga

Kerja pada UsahataniCabai Merah di

Desa Beganding Per Petani Per Musim Tanam, Tahun 2018

\begin{tabular}{|c|l|c|c|}
\hline No & $\begin{array}{l}\text { Kegiatan } \\
\text { Budidaya }\end{array}$ & $\begin{array}{c}\text { TKDK(H } \\
\text { KP) }\end{array}$ & $\begin{array}{c}\text { TKLK(H } \\
\text { KP) }\end{array}$ \\
\hline 1. & Pengolahan Lahan & 49.50 & 188.70 \\
\hline 2. & Persamaian & 93.70 & - \\
\hline 3. & Penanaman & 50.20 & 202.10 \\
\hline 4. & Penyiangan & 326.40 & 35.60 \\
\hline 5. & Pemupukan & 62.30 & - \\
\hline 6 & Penyemprotan & 69.60 & - \\
\hline $\mathbf{7}$ & Panen & 174.60 & 330.00 \\
\hline & Total & 825.60 & 755.90 \\
\hline & Rataan & 23.59 & 21.60 \\
\hline
\end{tabular}

Sumber: Data Diolah, Tahun 2018 
Dari Tabel3.3terlihatbahwa total tenagakerja yang digunakandalamusahatanicabaimerahselama satumusimtanamadalah1.581,30 dengan rata-rata $45.18 \mathrm{HKP}$, terdiridari825,60 HKP dengan rata-rata $23.59 \quad \mathrm{HKP}$ daridalamkeluargadan755,90 HKP dengan rata-rata 21,60 HKP dariluarkeluarga. Adapun nilai dengan rata-rata tenaga kerja yang digunakan dapat dilihat pada Tabel berikut.

Tabel Nilai Penggunaan Tenaga Kerja Pada Usahatani Cabai Merah di Desa Beganding Per Petani Per Musim Tanam, Tahun 2018

\begin{tabular}{|c|c|c|c|}
\hline $\begin{array}{l}\mathbf{N} \\
\mathbf{0}\end{array}$ & $\begin{array}{l}\text { Kegiatan } \\
\text { Budidaya }\end{array}$ & $\begin{array}{c}\text { TKDK } \\
(\mathrm{Rp})\end{array}$ & $\begin{array}{c}\text { TKLK } \\
(\mathrm{Rp})\end{array}$ \\
\hline 1 & $\begin{array}{l}\text { Pengolahan } \\
\text { Lahan }\end{array}$ & 3.896.000 & 14.888.000 \\
\hline 2 & Persamaian & 7.384 .000 & - \\
\hline 3 & Penanaman & 3.960 .000 & 15.936 .000 \\
\hline 4 & Penyiangan & 25.728 .000 & 2.808 .000 \\
\hline 5 & Pemupukan & 4.904 .000 & - \\
\hline 6 & $\begin{array}{l}\text { Penyemprot } \\
\text { an }\end{array}$ & 5.480 .000 & - \\
\hline 7 & Panen & 13.744 .000 & 26.008 .000 \\
\hline & Total & 65.096 .000 & 59.640 .000 \\
\hline & Rataan & 1.888 .686 & 1.728 .914 \\
\hline
\end{tabular}

Sumber: Data Diolah, Tahun 2018

Dari Tabel tersebut terlihat bahwa nilai tenaga kerja yang digunakan pada usaha tani cabai merah di daerah penelitian adalahRp 124.736.000 dengan rata-rata $\mathrm{Rp}$ 3.617.600.Nilai tenaga kerja dari dalam keluarga lebih besar disbanding tenaga kerja dari luar keluarga, yaituRp 1.888.686 TKDK dan Rp 1.728.914 TKLK. Nilai tenaga kerja tersebut diperoleh dengan mengalikan jumlah tenaga kerja terhadap upah tenaga kerja di daerah penelitian, yaitu Rp 80.000 per HKP.

\section{Penyusutan Peralatan}

Jenis peralatan usahatani cabai merah di daerah penelitian adalah cangkul, koret, parang, knapsaksprayer, ember, dan babat. Jumlah masing-masing peralatan yang dimiliki petani serta nilai dengan ratarata penyusutannya tertera pada Tabel 3.5.

Tabel Nilai Penyusutan Peralatan Pada Usahatani Cabai Merah di DesaBeganding Per Petani Per MusimTanam, Tahun 2018

\begin{tabular}{|c|l|r|r|}
\hline $\begin{array}{l}\mathbf{N} \\
\mathbf{0}\end{array}$ & \multicolumn{1}{|c|}{ Jenis } & Jumlah $(\mathbf{R p})$ & $\begin{array}{c}\text { Rataan } \\
(\mathbf{R p})\end{array}$ \\
\hline 1. & Cangkul & $\mathbf{7 0 0 . 0 0 4 , 0 0}$ & $\mathbf{2 0 . 0 0 0}$ \\
\hline 2. & Koret & $\mathbf{5 5 0 . 0 0 3 , 0 0}$ & $\mathbf{1 5 . 7 1 4}$ \\
\hline 3. & Parang & $\mathbf{3 4 0 . 0 0 1 , 0 0}$ & $\mathbf{9 . 7 1 4}$ \\
\hline 4. & $\begin{array}{l}\text { Knapsack } \\
\text { sprayer }\end{array}$ & $\mathbf{1 . 3 6 6 . 6 5 9 , 0 0}$ & $\mathbf{3 9 . 0 4 7}$ \\
\hline 5. & Ember & $\mathbf{4 4 2 . 6 7 3 , 0 0}$ & $\mathbf{1 2 . 6 4 8}$ \\
\hline 6. & Babat & $\mathbf{3 0 6 . 6 7 1 , 0 0}$ & $\mathbf{8 . 7 6 2}$ \\
\hline \multicolumn{2}{|c|}{ Total } & $3.706 .001,00$ & 105.886 \\
\hline
\end{tabular}

Sumber: Data Diolah Tahun 2018

Dari Tabel3.5terlihatbahwa total nilaipenyusutanperalatanpadausahatanicabai merah di daerahpenelitianadalah Rp 3.706.001,00 dengan rata-rata Rp. 105.886 per petani. Penyusutan terbesar bersumber dari peralatan knapsacksprayer dan cangkul. Sedangkan penyusutan dari peralatan lainnya relatif kecil.

\section{Total Biaya Produksi}

Biaya produksi pada penelitian ini bersumber dari nilaidengan rata-rata sarana produksi, tenaga kerja, dan penyusutan peralatan serta pajak, seperti tertera pada Tabel berikut. 
Tabel Total Biaya Produksi Pada Usahatani Cabai Merahdi Desa Beganding Per Petani Per Musim Tanam,Tahun 2018

\begin{tabular}{|c|l|c|c|}
\hline $\begin{array}{l}\text { N } \\
\text { o. }\end{array}$ & Jenis & Total & $\begin{array}{c}\text { Rataan } \\
(\text { Rp) }\end{array}$ \\
\hline 1. & $\begin{array}{l}\text { Saranaprodu } \\
\text { ksi }\end{array}$ & 127.550 .500 & 3.644 .300 \\
\hline 2. & Tenaga kerja & 126.616 .000 & 3.617 .600 \\
\hline 3. & $\begin{array}{l}\text { Penyusutan } \\
\text { alat }\end{array}$ & 3.706 .011 & 105.886 \\
\hline 4. & Sewa jetor & 7.185 .000 & 205.286 \\
\hline 5. & PBB & 1.437 .000 & 41.057 \\
\hline \multicolumn{2}{|c|}{ Total } & $\mathbf{2 6 6 . 4 9 4 . 5 1 1}$ & $\mathbf{7 . 6 1 4 . 1 2 9}$ \\
\hline
\end{tabular}

Sumber: Data Diolah,Tahun 2018

Dari Tabel di atas terlihat bahwa total biaya produksi di daerah penelitian adalah sebesar Rp 266.494.511 dengan rata-rata Rp7.614.129 per musim tanam per petani. Sebagian besar dari biaya produksi tersebut merupakan biaya sarana produksi sebesar Rp3.644.300 dan biaya tenaga kerja sebesar Rp3.617.600.

\section{Produksi dan Harga}

Tabel Produksi Sebelum dan Sesudah

Erupsi Gunung Sinabung pada

Usahatani Cabai Merah di Desa

Beganding PerPetani Per Musim Tanam, Tahun 2018

\begin{tabular}{|l|l|c|c|}
\hline No. & Jenis & Jumlah & Rataan \\
\hline 1. & $\begin{array}{l}\text { Produksi } \\
\text { sebelum } \\
\text { erupsi Gunung } \\
\text { Sinabung }(\mathrm{Kg})\end{array}$ & 67.630 & 1.932 \\
\hline 2. & $\begin{array}{l}\text { Produksi } \\
\text { sesudah erupsi } \\
\text { Gunung } \\
\text { Sinabung }(\mathrm{Kg})\end{array}$ & 46.980 & 1.342 \\
\hline & Perbedaan & $\mathbf{2 0 . 6 5 0}$ & $\mathbf{5 9 0}$ \\
\hline
\end{tabular}

Sumber: Data Diolah Tahun 2018
Dari Tabel 3.7 terlihat bahwa jumlah produksi usahatani cabai merah sebelum erupsi Gunung Sinabung sebesar $67.630 \mathrm{~kg}$ dengan rata-rata $1.932 \mathrm{~kg}$ dan pengaruh erupsi Gunung Sinabung terhadap cabai merah menyebabkan penurunan Produksi sesudah erupsi Gunung Sinabung menjadi $46.980 \mathrm{~kg}$ dengan rata-rata $1342 \mathrm{~kg}$ dan perbedaan sebesar 20.650 kgdengan ratarata $590 \mathrm{~kg}$. Menurunnya produksi cabai merah menyebabkan peningkatan harga cabai merah, seperti tertera pada Tabel 3.8

Tabel Harga Sebelum dan Sesudah erupsi Gunung SinabungpadaUsahatani Cabai Merah di Desa Beganding PerPetani Per Musim Tanam, Tahun 2018

\begin{tabular}{|l|l|c|c|}
\hline No. & Jenis & Jumlah & Rataan \\
\hline 1. & $\begin{array}{l}\text { Harga sebelum } \\
\text { erupsi Gunung } \\
\text { Sinabung (Rp) }\end{array}$ & 440,350 & 12,581 \\
\hline 2. & $\begin{array}{l}\text { Harga sesudah } \\
\text { erupsi Gunung } \\
\text { Sinabung (kg) }\end{array}$ & 518,650 & 14,819 \\
\hline & Perbedaan & $\mathbf{7 8 , 3 0 0}$ & $\mathbf{2 , 2 3 7}$ \\
\hline
\end{tabular}

Sumber: Data Diolah Tahun 2018

Dari Tabel 3.8 terlihat bahwa total harga cabai merah sebelum erupsi Gunung Sinabung sebesar Rp 440.350 dengan ratarata $\mathrm{Rp} 12.581$ dan pengaruh erupsi Gunung Sinabung terhadap cabai merah menyebabkan kenaikan harga sesudah erupsi Gunung Sinabungmenjadi Rp 518,650 dengan rata-rata14,819 dan perbedaan sebesar Rp 78,300dengan rata-rata $\operatorname{Rp} 2,237$.

Perbedaan Produksi Sebelum dan Sesudah Erupsi Gunung Sinabung

Erupsi gunung Sinabung telah mengganggu pertanian di Kabupaten Karo, dimana lahan-lahan usahatani menjadi tidak subur sebagai akibat semburan abu vulkanik. $\mathrm{Abu}$ vulkanik tersebut bersifat asam 
sehingga menyebabkan lahan pertanaman menjadi tanah asam. Kondisi tersebut menyebabkan pertumbuhan tanaman menjadi terganggu, dan menyebabkan produksi menjadi merosot. Perbedaan produksi antara sebelum dan sesudah erupsi gunung Sinabung dapat dilihat pada tabel berikut, dengan rata-rata sebagai berikut:

Tabel Perbedaan Produksi Usahatani Cabai Merah Sebelum dan Sesudah Erupsi Gunung Sinabung, Tahun 2018

\begin{tabular}{|l|r|}
\hline \multicolumn{1}{|c|}{ Uraian } & \multicolumn{1}{c|}{ Nilai } \\
\hline ProduksiSebelum & 1.932 \\
Erupsi (kg) & \\
ProduksiSetelahEr & 1.342 \\
upsi (kg) & 590 \\
\hline Selisih (kg) & $12.24 *$ \\
Nilai t-hitung & 2,65 \\
Nilai t-tabel 5 \% & \\
\hline
\end{tabular}

Sumber: Data Diolah Tahun 2018

Dari Tabel di atas terlihat bahwa rataan produksi tanaman cabai merah setelah erupsi gunung Sinabung lebih rendah disbanding produksi cabai merah sebelum erupsi gunung Sinabung, dengan perbedaan sebesar Rp.590 kg per petani. Hasil uji statistic uji beda rata-rata dapat dilihat pada Tabel berikut.

Tabel Hasil Uji Beda Rata-rata Produksi Usahatani Cabai Merah Sebelum dan Sesudah Erupsi Gunung Sinabung

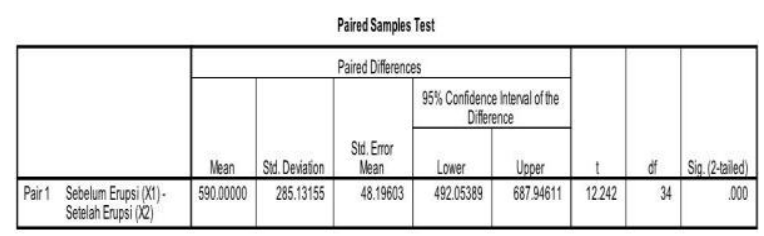

Sumber: Data Diolah Tahun 2018

Hasilujistatistik menunjukkan bahwa nilai t-hitung 12,24 lebih besar dari nilai ttabel $5 \%$ sebesar2,65 ( $t_{\text {hitung }} 12,24 \geq$ $t_{\text {tabel }} 2,65 ;$ tolak $H_{0}$ : terima $H_{1}$ ), yang berarti bahwa produksi usahatani cabai merah setelah erupsi gunung Sinabung berbe dan nyata/signifikan lebih rendah disbanding produksi tanaman sebelum erupsi gunung Sinabung, dengan tingkat kepercayaan $95 \%$. Hipotesis yang menyatakan bahwa terdapat perbedaan yang nyata/signifikan produksi cabai merah di lokasi penelitian sebelum dan sesudah erupsi gunung Sinabung, dapat diterima.

\section{Perbedaan Harga Jual Sebelum dan Sesudah} Erupsi Gunung Sinabung Tahun 2018

Lebih rendahnya produksi tanaman cabai merah setelah erupsi gunung Sinabung menyebabkan jumlah penawaran produksi menjadi lebih rendah dibanding permintaan terhadap produksi tanaman cabai merah. Jika penawaran lebih rendah dari permintaan maka harga cabai merah akan meningkat.Keadaan tersebut menyebabkan harga cabai merah setelah erupsi gunung Sinabung menjadi lebih tinggi, seperti tertera pada tabel, dengan rata-rata sebagai berikut:

\section{Tabel Perbedaan Harga Jual Usahatani Cabai Merah Sebelum dan Sesudah Erupsi Gunung Sinabung, Tahun 2018}

\begin{tabular}{|c|c|}
\hline Uraian & Nilai \\
\hline $\begin{array}{l}\text { HargaSebelumEr } \\
\text { upsi (Rp/kg) }\end{array}$ & 12.581 \\
\hline $\begin{array}{l}\text { HargaSetelahEru } \\
\text { psi (Rp/kg) }\end{array}$ & 14.819 \\
\hline Selisih (Rp/kg) & 2.237 \\
\hline Nilai t-hitung & $-21.99 *$ \\
\hline Nilai t-tabel $5 \%$ & 2,035 \\
\hline
\end{tabular}

Sumber: Data Diolah Tahun 2018

Dari Tabel tersebut terlihat bahwa rataan harga jual produksi cabai merah setelah erupsi gunung Sinabung lebih tinggi disbanding 
produksi cabai merah sebelum erupsi gunung Sinabung, dengan perbedaan sebesar Rp 2.237 per kg cabai merah.

Pada tabel tertampil, hasil uji statistik menunjukkan bahwa nilai t-hitung sebesar 21,99 lebih besar dari nilai t-tabel $5 \%$ sebesar $2,035\left(t_{\text {hitung }}-21,99 \leq t_{\text {tabel }} 2,035\right.$;

terima $H_{0}$ : tolak $H_{1}$ ), yang berarti bahwa harga jual usahatani cabai merah setelah erupsi gunung Sinabung terdapat perbedaan lebih rendah disbanding produksi tanaman sebelum erupsi gunung Sinabung, dengan tingkat kepercayaan 95\%. Hipotesis yang menyatakan bahwa tidak terdapat perbedaan yang nyata harga cabai merah dan produksi cabai merah di Kabupaten Karo sebelum dan sesudah Erupsi Gunung Sinabung, hipotesis ditolak. Hasil ujistatistik uji beda rata-rata dapat dilihat pada table berikut.

\section{Tabel Hasil Uji Beda Rata-rata Harga Cabai Merah Sebelum dan Sesudah Erupsi Gunung Sinabung}

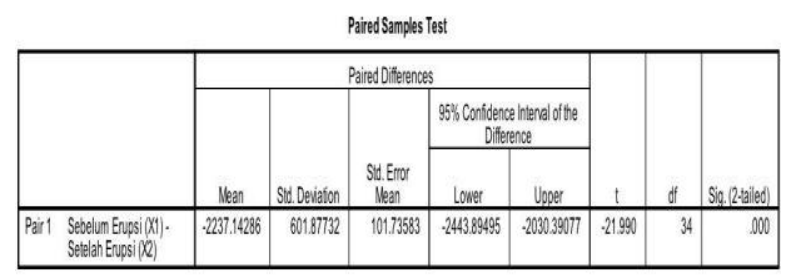

Sumber: Data diolah tahun 2018

Perbandingan Pendapatan dengan UMK Setelah Erupsi Gunung Sinabung Tahun 2018

Sebelumnya telah dijelaskan bahwa erupsi gunung Sinabung telah menyebabkan kemerosotan produksi usahatani cabai merah dan menyebabkan peningkatan harga jual produksi cabai merah. Tetapi pada dasarnya bahwa peningkatan harga tersebut tidaklah dapat mengkompensasi penurunan produksi yang relatif besar, sehingga tentu akan menyebabkan pendapatan usahatani cabai merah di daerah penelitian menjadi rendah. Tinggi rendahnya tingkat pendapatan usahatani cabai merah dalam penelitian ini diukur dengan menggunakan acuan Upah Minimum Kabupaten (UMK) di Kabupaten
Karo, pada Tabel 3.13 terlihat bahwa pendapatan bersih usahatani cabai merah di daerah penelitian adalah sebesar $\mathrm{Rp}$. 12.307.600. Setelah dibagi dengan jumlah bulan dalam satu musim tanam, yaitu 6 bulan, maka diperoleh pendapatan usahatani per bulan sebesar Rp 2.051.267 per bulan. Jumlah pendapatan tersebut lebih rendah dibanding dengan UMK Kabupaten Karo sebesar Rp2.619.234,41, sehingga hipotesis yang menyatakan bahwa tingkat pendapatan petani cabai merah sesudah erupsi gunung Sinabung tergolong rendah dibanding UMK di Kabupaten Karo, hipotesis ditolak. Seperti tertera pada dengan rata-rata pada Tabel berikut.

Tabel Perbandingan Pendapatan Bersih Usahatani Cabai Merah dengan UMK Kabupaten Karo, tahun 2018

\begin{tabular}{|l|l|c|}
\hline No. & Jenis & Rataan \\
\hline 1. & Produksi (kg) & 19.921 .729 \\
\hline 2. & Penerimaan (Rp) & 7.614 .129 \\
\hline 4. & $\begin{array}{l}\text { PendapatanBersih } \\
(\text { Rp) }\end{array}$ & 12.307 .600 \\
\hline 5. & $\begin{array}{l}\text { PendapatanBersih } \\
\text { (Rp/bulan) }\end{array}$ & 2.051 .267 \\
\hline 6. & $\begin{array}{l}\text { UMK } \\
\text { (Rp/bulan)untuktahu } \\
\text { n 2017 }\end{array}$ & $\begin{array}{c}\text { Lebihrendahdari } \\
\text { UMK }\end{array}$ \\
\hline & Keterangan & \\
\hline
\end{tabular}

Sumber: Data Diolah Tahun 2018

\section{KESIMPULAN DAN SARAN}

\section{Kesimpulan}

Berdasarkan hasil penelitian maka dapat disimpulkan sebagai berikut:

1. Terdapat perbedaan yang nyata produksi cabai merah di daerah penelitian sebelum dan sesudah erupsi gunung Sinabung. Produksi usahatani cabai merah sebelum erupsi gunung Sinabung 
sebanyak $1.932 \mathrm{~kg}$ per petani lebih tinggi dibanding setelah erupsi Gunung Sinabung sebaynak $1.342 \mathrm{~kg}$ per petani, dengan selisih $590 \mathrm{~kg}$ per petani.

2. Terdapat perbedaan yang tidak nyata harga produksi cabai merah di daerah penelitian sebelum dan sesudah erupsi gunung Sinabung. Harga jual produksi usahatani cabai merah sebelum erupsi gunung Sinabung sebanyak Rp12.581 per $\mathrm{kg}$ lebih rendah dibanding setelah erupsi Gunung Sinabung sebesar Rp 14.819 per $\mathrm{kg}$, dengan selisih $\mathrm{Rp} 2.237$ per kg.

3. Pendapatan usahatani cabai sebelum dan sesudah erupsi gunung Sinabung tergolong rendah,karena lebih rendah dari UMK. Pendapatan usahatani cabai merah per bulan sebesar Rp 2.051.267per bulan, sedangkan UMK Kabupaten Karo untuk tahun 2018 adalah sebesar Rp2.619.234,41.

\section{Saran}

Kalangan akademisi pertanian perlu mencari cara untuk segera dapat mengatasi kerusakan yang ditimbulkan sebagai akibat erupsi gunung Sinabung, sehingga hasil penelitian tersebut dapat diterapkan oleh petani untuk meningkatkan hasil produksi cabai merah.

\section{DAFTAR PUSTAKA}

Dinas Pertanian Kabupaten Karo 2017. Produksi dan Rata-Rata Harga Cabai Merah di Kabupaten Karo.

Dinas Pertanian dan Perkebunan Kabupaten Karo Tahun 2017.Produksi Tanaman Cabai Merah (Ton) di Kabupaten Karo menurut Kecamatan.

Dinas Pertanian dan Perkebunan Kabupaten Karo. 2014. Statistika Pertanian 2010.
Martini, T., Setyono, B., dan Sudarmaji. 2011. Dampak Erupsi Gunung Sinabung Terhadap Usahatani Bunga Krisan. Balai Pengkajian Teknologi Pertanian. Yogyakarta.

Pebriyanti. 2016. Dampak Erupsi Gunung Sinabung Terhadap Produksi Dan Harga Buah dan Sayuran di Kabupaten Karo.

Soekartawi. 2002. Analisis Usahatani. Penerbit Universitas Indonesia. Jakarta.

Tindaon, F. 2003. Letusan Gunung Sinabung Tingkatkan Kesuburan Tanah. 